\title{
A Lesson Learned? The Image of Poland during World War II Presented by Recent German Literature and Its Perception in Public Discourses
}

\begin{abstract}
Aвstract: Based on Wolf Schmid's Narratology, this article depicts the influence of the so-called abstract dimension on the reception of Kevin Vennemann's Nahe Jedenew (Close to Jedenew, 2005) and Matthias Nawrat's Die vielen Tode unseres Opas Jurek (Numerous Deaths of Grandpa Jurek, 2015). The abstract dimension - being, among others, the result of personal beliefs and individual "literary experiences" - helps to understand contradictory opinions about the same work and depends often (but not exclusively) on different historical knowledge and awareness. The reception in the media and academic discourse reveals schemata that cannot be explained by the text alone. I argue that the recipient is highly influenced by the author's personal background, although it is not about autobiographies - which clearly reduces options for interpretation.
\end{abstract}

KeY wORDs: Kevin Vennemann, Matthias Nawrat, reception processes, literary criticism, media and scientific discourse

\section{Introduction - Poland, the Still "Unknown" Neighbour}

In the context of this article, I am interested in the image of Poland spread by recent German literature dealing with Germany's darkest historical chapter, the Holocaust and World War II. In an age of tenser political relationships between both countries and global political polarisation, the impact of artistic projects and especially the media response cannot be underestimated, as the discussion about the German mini-series Unsere Mütter, unsere Väter demonstrated: critics considered the depiction of the brave, naive soldiers and nurses to be a release 
strategy for the German historical consciousness. Besides, in Germany the lack of readiness to understand the dismayed Polish reactions to the depictions of the Home Army was astonishing. ${ }^{1}$ Although it would be going too far to accuse the producers of historical distortion, because of the lack of empathy and diversification in representing history, the board of directors at the broadcaster ZDF discredited themselves. As a gesture of reconciliation, ZDF showed Jan Komasa's Warsaw '44 in the summer of 2015, and almost every German critic referred to the prefatory discussion about Unsere Mütter, unsere Väter, ${ }^{2}$ which Katarzyna Chimiak sums up accurately: "For many Germans, Poland is still an unknown - and therefore misunderstood and viewed through the prism of negative stereotypes - neighbour."3

This debate made it clear that the question of historical awareness is highly emotional and hard to translate into other national contexts. But besides historically questionable depictions and topics that occur in plenty of literary and filmic examples, there is also a second level of this question that influences and forms the reciprocal perception of Poles and Germans, operating with a very subtle system of references and images on the textual level. The Slavicist Wolf Schmid bases his narratology theory on three levels of communication: first, the fictional dimension that refers to the characters and their speeches in the text (=entities of the fictional world presented in a story); second, the concrete dimension of the real existing author and the readers (=external entities not connected with the story itself); and third, the abstract dimension that in a certain way is the connecting link between the two aforementioned levels. I aim at showing that this abstract dimension - which is a product of personal beliefs and individual reading experiences - helps to explain contradictory opinions about the same literary work, depending often (but not exclusively) on the different historical knowledge and background of the readership.

The reception in the media and scientific discourse also mirrors schemata and discourses that cannot be explained by the work alone. I argue that the recipient is strongly influenced by the personal story of the author despite the fact that both books I am going to analyse are not autobiographies. Kevin Vennemann's Close to Jedenew (2005) and Matthias Nawrat's The Numerous Deaths of Grandpa Jurek (2015) draw completely different pictures of Poland. While the first author

${ }^{1}$ K. Chimiak: Unsere Mütter, unsere Väter - Ein Beispiel für historische Unwissenheit und deutsche Stereotype, https://zeitgeschichte-online.de/themen/unsere-muetter-unsere-vaeter-einbeispiel-fuer-historische-unwissenheit-und-deutsche [accessed 13.07.2020].

${ }^{2}$ E.-M. Hiemer: "Der Zweite Weltkrieg im polnischen Kino. Jüngste filmische Annäherungen und deren Rezeption in Polen und Deutschland.” Poznańskie Studia Slawistyczne 2017, no. 12 , pp. 123-138.

${ }^{3}$ K. Chimiak: Unsere Mütter...: "Polen ist noch immer für viele Deutsche ein unbekannter - und deshalb unverstandener und durch das Prisma von negativen Stereotypen betrachteter Nachbar." 
aims at a narrative appropriation of one of the most crucial lieux de mémoire in Polish history, the Jedwabne massacre, Nawrat tries to understand the country of his origin, which he left at the age of ten, by depicting sixty years of Polish history. I intend to find answers to the question to what extent the author's personal background and the choice of certain narrative styles make a narration questionable or acceptable for the recipients and which other (but overlooked) interpretative options the texts provide. Starting from a theoretical sketch about the abstract dimension of text analysis, I sum up the authors' biographies and oeuvres and shed light on the German and Polish academic and media echoes which the two books provoked. My aim is to reveal the interrelationship between the image of an author, the represented topic and the reactions to it.

\section{About the Abstract Text Dimension}

The text theory of Wolf Schmid, which is strongly influenced by structuralist convictions, considers the author to have primarily a text-external function: the concrete author truly exists, "even if he had never put pen to paper." ${ }^{\prime \prime}$ In this respect Schmid sees no direct connection between him/her and the written text. However, every linguistic message, and thus also that of the author, contains an image of its creator. With the help of the linguistic sign, the sender expresses himself and leaves signals in the text that create an image of him. It is thus a semantic category that is constructed by the reader and not a narrative instance, as e.g. Martina Wagner-Engelhaaf puts it.

A basis for consensus should be provided by the definition of the abstract author as the correlate of all indexical signs in a text that point to the author. These signs delineate both an ideological position and an esthetic conception. "Abstract" does not mean "fictive." The abstract author is not a represented entity, nor an intentional creation of the concrete author, and is categorially distinguished in this way from the narrator, who is always - whether explicitly or implicitly - a represented entity. [...] The abstract author is only the anthropomorphic hypostasis of all creative acts, the personified intention of the work. ${ }^{5}$

The narrator's speech and text provide clues to the image of the abstract instances, which Schmid describes as indicative signs, but that does not change the fact that the abstract author remains a constructed product. In contrast to the concept of the implied author according to Wayne Booth, those images are

\footnotetext{
${ }^{4}$ W. Schmid: Narratology. An Introduction. Berlin 2010, p. 36.

${ }^{5}$ Ibidem, p. 48.
} 
not intended by the concrete author. Booth's concept is therefore problematic, since the abstract author image created by the reader may refer to political or other ideological attitudes which the concrete author simply does not stand for. ${ }^{6}$ "Many authors realize possibilities in their work which must remain unrealized in life, and take up positions which, for whatever reasons, they would not want to, or be able to, propose in real life."

The abstract text dimension is completed by the abstract reader. According to the linguistic approach to narratology, a written text also includes hints that give information about the abstract image of the reader. This picture is made of two parts: the presumed reader (= addressee/Adressat), the presumed or desired receptive instance, and the actual recipient (= recipient/Rezipient), the real reader. The abstract reader is the image that served the concrete author during the writing process to adapt linguistic and content-related codes. None of these entities belong to the narrated world. In his role as recipient, the reader is free to deepen the sensual, emotional and cognitive content of the work. ${ }^{8}$ Schmid postulates that in every work there are references to an optimal way of reading, which the so-called ideal recipient can recognise.

With regard to the analysed works, this theoretical frame leads to the following questions: Does the depiction of an ideal recipient between the lines enable us to solve misunderstandings in interpretation? And what do divergent interpretations reveal about the recipient's cultural and historical background?

\section{Constructing the "East": Kevin Vennemann's Close to Jedenew (2005)}

Vennemann, born in 1977 in Westphalia, released his second novel in 2005, a work which was highly appreciated especially due to its stylistic features. Books dealing with Jewish or wartime topics more easily succeed on the German book market, and Polish literature especially has gained much attention in this respect, whereas other important Polish authors have to overcome a cultural reception barrier. ${ }^{9}$ In the case of Close to Jedenew, the roles seem to be inverted: here it is

${ }^{6}$ E.-M. Hiemer: Autobiographisches Schreiben als ästhetisches Problem. Jüdische Vielfalt in der polnischen und deutschen Gegenwartsliteratur. Wiesbaden 2018, p. 26.

7 W. Schmid: Narratology..., p. 49.

${ }^{8}$ Ibidem, p. 57.

9 D. Uffelmann: "Deutscher Kommerz mit polnischer Literatur über jüdische Themen: Maria Nurowska, Andrzej Szczypiorski und Dariusz Muszer." In: Osteuropäisch-jüdische Literaturen im 20. und 21. Jahrhundert. Identität und Poetik = Eastern European Jewish Literature of the 20th and 21st Centuries. Ed. K. Smola. München 2013, pp. 299-300. 
a German author shedding light on historical events taking place in Eastern Europe. ${ }^{10}$ It is hard to describe the main plot, since Vennemann's female narrator uses the technique of repetition and elliptic narration. The reader is directly introduced into the event: two nameless twin sisters are escaping from the pogrom taking place in their village where Polish peasants are destroying their house, armed and driven to this by foreign soldiers; the sisters observe the situation from their tree house but give the reader only a very vague impression of the events. The main role is played by flashbacks to their childhood and family life. They seem to belong to an assimilated Jewish family where Jewishness never was a crucial topic of self-identification. Since the narrator repeats family stories or scenes from rural life, the narration follows a music-like rhythm and contrasts in a paradoxical manner the beautiful childhood memory with the cruel wartime reality.

Whereas for every reader who is familiar with Polish history and Holocaust remembrance, it seems to be a camouflaged novel about the Jedwabne pogrom, the ordinary German reader perceives another scenario. The text is intentionally short on spatiotemporal references, thus the toponyms occurring in this text sound generally "Slavic" to him or her, rather than specifically Polish. In the German original passage one reads "our maternal relatives from Ladow or our aunt and her husband and family from Nadice or the relatives of Antonina's mother from Julowice or Warsznar's family from Kradejew." ${ }^{11}$ The action is supposed to be set in the southern Lithuanian heathland ${ }^{12}$ which calls into question the use of only Polish-sounding family names like Krystowczyk, Dzielski, Sobuta and Geniek. What especially German literary critics understand as a conscious and persistent absence of references (durchgehender Referenzverzicht ${ }^{13}$ ), which makes the narration adjustable to other contexts, at second glance turns out to reflect lack of knowledge. The most obvious example is the wrong usage of the affectionate form of Katarzyna, which is - at least in the German version - Kacia. One might have blamed this on careless editing, but the narrator even explains this usage several times, ${ }^{14}$ which causes - unintentionally - a ridiculous effect that the average non-Polish reader would not identify. The inconsistent naming of people and places thus creates the impression of an undifferentiated view of East (sic!)

${ }^{10}$ S. Kramer: "Identifying with the Victims in the Land of the Perpetrators: Iris Hanika's Das Eigentliche and Kevin Vennemann's Nahe Jedenew." In: Persistent Legacy - The Holocaust and German Studies. Ed. E. McGlothlin, J.M. Kapczynski. Rochester, NY, 2016, pp. 159-177.

${ }^{11}$ K. Vennemann: Nahe Jedenew. Frankfurt am Main 2005, p. 23: "unsere Verwandtschaft mütterlicherseits aus Ladow oder unsere Tante und ihr Mann samt Familie aus Nadice oder die Verwandtschaft von Antoninas Mutter aus Julowice oder Wasznars Familie aus Kradejew."

${ }_{12}$ Ibidem, p. 75.

${ }^{13}$ K. Frieden: Neuverhandlungen des Holocaust: mediale Transformationen des Gedächtnisparadigmas. Bielefeld 2014, p. 76.

${ }^{14}$ K. Vennemann: Nahe Jedenew..., pp. 26, 47, 116: "Katarzyna, Kacia, wie wir sie nennen..." 
Europe. Additionally, the text does not lack stereotypical representations: the noisy and drinking Polish peasants are constantly singing, which refers to one of the oldest stereotypes of the Slavic character as being mainly lyrical, ${ }^{15}$ which is rooted in Johann Gottfried Herder's image of the tender Slavic realm which loves the peasant life. ${ }^{16}$ According to Pascal Fagot's study about Poland as a main topic of German postwar literature, German narrators are too prejudiced during their journeys through Poland, which does not allow them to open up towards the country and its people. ${ }^{17} \mathrm{He}$ depicts exit strategies for the narrator on how to avoid unpleasant hegemonic or historical controversies: authors choose to depict parallel universes of regional minorities. Vennemann also aims at avoiding historical discussions by adopting the presumably innocent children's point of view. This "highly emotionalising perspective of a victim"18 can be understood everywhere in every context and does not demand historical correctness.

The narrator largely ignores the perceived acts of violence; he [the author - E.M. H.] thus takes an ethical position beyond horror and kitsch. In the case of Close to Jedenew, one could also speak of an ethics of the gaze [emphasis added] which means that the perception and experience of the witnesses cannot be fully conveyed by language. Vennemann's literary fiction does justice to this psychological component because his novel questions narrativity, linearity and coherence, thus avoiding transferring historical violence and trauma experience into a conventional narrative order and possibly interpreting it. ${ }^{19}$

This can be seen as evidence for the abstract reader who is in Vennemann's case a universal European reader. Younger authors tend to write about European

15 A. Kochanowska-Nieborak: Das Polenbild in Meyers Konversationslexika des, langen' 19. Jahrhunderts. Frankfurt 2010, p. 228.

${ }^{16}$ J.G. Herder: Ideen zur Philosophie der Geschichte der Menschheit, Band 2. Berlin-Weimar 1996, pp. 279-282.

${ }_{17}$ P. Fagot: Mémoires et regards. Le thème de la Pologne dans la prose littéraire allemande (1949-1990). Frankfurt 2001, p. 331.

${ }^{18}$ A. Rutka: "Kinderperspektive und Märchenform als Modi der erinnerungslosen Auseinandersetzung mit der Shoah in aktuellen Roman der dritten Generation." Roczniki Humanistyczne 2017, no. 5, p. 106.

${ }^{19}$ C. Hähnel-Mesnard: "Die Inszenierung von Zeugenschaft im Roman Nahe Jedenew (2005) von Kevin Vennemann." In: Der Nationalsozialismus und die Shoah in der deutschsprachigen Gegenwartsliteratur. Ed. T. Fischer, P. Hammermeister, S. Kramer. Amsterdam 2014, pp. 168-186, here 172-173: "Die Erzählerin klammert die wahrgenommenen Gewalttaten weitgehend aus; er [der Autor, E.-M. H.] nimmt so eine ethische Position jenseits von Horror und Verkitschung ein. Man könnte im Falle von Nahe Jedenew auch von einer Ethik des Blickes sprechen, die dem Leser bedeutet, dass die Wahrnehmung und die Erfahrung der Zeugen nicht vollständig durch Sprache vermittelt werden kann. Vennemanns literarische Fiktion wird dieser psychologischen Komponente gerecht, indem sein Roman Narrativität, Linearität und Kohärenz infrage stellt und es so vermeidet, geschichtliche Gewalt und Trauma-Erfahrung in eine konventionelle erzählerische Ordnung zu überführen und eventuell zu deuten." 
history in a way that is free from binational historical narrations and that uses fictional devices not in order to negate the past but to make history a common European topic. ${ }^{20}$

\section{Close to Jedenew: Academic and Public Reactions}

The author himself is surprisingly conscious of the problematic content for foreign readers since he comments in the Polish edition as follows:

Indeed, I was a little uncomfortable about it. The first translator had rejected the book because for her it was too much about Polish guilt and Polish perpetrators. But I didn't want to relativise anything. But some things in this novel remain a bit vague or ambiguous actually - and it was motivated by this thought that I wrote my second novel, Mara Kogoj. It's all about the continuity of history that characterises Carinthia to this day. ${ }^{21}$

\section{Is a German Allowed to Do This? Polish Reactions to Close to Jedenew}

Generally speaking, reactions in Poland are divided about this book. The main concern is the obvious gaming with the true history of Jedwabne, but a lot of critics refer to the author personally: the most emotional review was written by Paweł Smoleński for Gazeta Wyborcza: "A German took the liberty, for God's sake, of saying something that, because of his birth, his mother tongue, his grandfather marching across Europe under a banner with a broken cross,

${ }^{20}$ Anne Hultsch asserts a tendency towards universal European topics in recent Czech literature, too, and argues that these narratives run the risk of superficiality. A. Hultsch: "Schreiben, um übersetzt zu werden? Tschechische Literatur zwischen Originalität und ,euroromán.." Zeitschrift für Slawistik 2010, no. 55/4, pp. 464-479.

${ }^{21}$ G. Dietz: Hitler Sells, https://taz.de/Archiv-Suche/!5186550\&s=georg\%2Bdiez\%2Bvennema $\mathrm{nn} /$ [accessed 11.07.2020]. "Und mir war etwas unangenehm dabei. Die erste Übersetzerin hatte das Buch abgelehnt, weil es ihr zu sehr um polnische Schuld ging und um polnische Täter. Ich wollte damit aber gar nichts relativieren. Aber manches bleibt in diesem Roman wohl tatsächlich etwas vage oder missverständlich - und auch aus diesem Gedanken heraus habe ich meinen zweiten Roman geschrieben, Mara Kogoj. Hier geht es eben um die Kontinuitäten der Geschichte, die Kärnten bis heute prägen." 
should be a restricted subject." ${ }^{22}$ It is the young age of 28 years at which Vennemann published his short novel that Smoleński considers to be the only excuse for dealing with the Jedwabne topic in such a careless manner. "A thirty-year-old is allowed to do things that aren't permitted of older people." ${ }^{23}$ Of course, literary reviews are not supposed to be neutral, but this remark shows a very paternalistic view and a deprecation of younger writers, as if they may use literature as a mental playground but have to get serious when growing up to become a "true" writer. Paradoxically, the children's point of view is linked with the writer's young age, and the fictional spatiotemporal setting is therefore taken as proof of the novel's lack of seriousness. Regardless of the fact that Polish literature ${ }^{24}$ has been making use of exactly the same narrative repertoire for decades, the review shows that the author's passport weighs more than literary qualities and is a perfect example of the influence of the abstract author's image which is created during the reading process. With regards to the literary qualities of the book, Smoleński criticises the lack of facts and especially the missing information about the German perpetrators - the book only refers to them anonymously as "the soldiers." Smoleński's point of view is both understandable and problematic. His reaction shows that Vennemann touched upon a highly vulnerable point in Polish history and at the same time was not conscious of the explosive effect that his little book might have in the neighbouring country. The peasants are constantly marked by the adjective "Polish" or "from Jedenew," but these attributes were deleted in subsequent translations and editions, changes aiming to show that "anti-Semitism is not limited to a specific group of perpetrators." 25

Smoleński's review reveals a rather traditional way of thinking about art and the artistic representation of history. In combination with Vennemann's quite naive self-perception as author, controversies seem to be inevitable. Vennemann belongs to a generation which does not question the responsibility for war crimes. At the same time, a strong detachment from national narrations and especially from institutionalised commemoration can be ascribed to younger authors in Germany. And the privatisation of memory is a process that can be observed in various literatures and it is not only an "allowed" topic for those whose families were directly concerned with the Holocaust and World War II. Therefore, it seems inappropriate to label Vennemann a writer of the "third generation after

${ }^{22}$ P. Smoleński: Co wolno młodemu Niemcowi, https://wyborcza.pl/1,75410,4559484.html [accessed 13.07.2020]. "Niemiec poważył się, do jasnej cholery, na coś, co dla niego z racji urodzenia, ojczystego języka, dziadka maszerującego przez Europę pod sztandarem z połamanym krzyżem winno być tematem zastrzeżonym."

${ }^{23}$ Ibidem: "Trzydziestolatkom wolno to, czego nie wolno starszym."

${ }^{24}$ See for example the books by Piotr Paziński, Zyta Rudzka, Igor Ostachowicz, or Irek Grin.

${ }^{25}$ C. Hähnel-Mesnard: Die Inszenierung..., p. 178: "So wird Antisemitismus nicht auf eine bestimmte Tätergruppe beschränkt." 
Shoah"26 since we simply do not know his family background. One can say that Vennemann tried to leave his mononational background and wanted to explore another nation's lieu de mémoire, not in order to re-interpret it but rather to show what everybody can learn from this tragic historical example. "That's why I reject this kind of personal-emotional storytelling. This generational novel. This need to clarify what the grandfather did to shed light on personal entanglements. [...] You just happen to have the same passport."27

It is hard to say if Smoleński knew about Vennemann's statements on the book while preparing his review, but one can surely blame Vennemann for lacking empathy towards other nations' wounds which he (consciously or not) opened up with Close to Jedenew: "I am perfectly aware that I didn't do anything. For me [writing about history - E.-M. H.] is my duty as a human, not as a German. ${ }^{\text {"28 }}$

Agata Pyzik wrote a more positive review of Vennemann's novel in Polityka. Even if she also warns of the abuse of the children's perspective, the seemingly outrageous combination of a German writing about Jedwabne presents interesting new points of view in her opinion - but she avoids naming them directly. In contrast to Smoleński, she only assumes that the novel could be about the Jedwabne pogrom but prefers to stress the (un)logic of Vennemann's literary construction.

Venemann's vision has more in common with Singer than Kosiński: there is no literal cruelty here, there is a visual image filtered through the child's imagination, full of disturbing anticipation. Because we know that tragedy is about to happen here. But so far, we are listening to a story suspended in timelessness, because the child perceives the passing time differently. ${ }^{29}$

Pyzik also argues that the image of the rural life is often not convincing but generally welcomes a different perspective on this part of Polish history, with which "we still haven't come to terms despite the common national discussion." 30

26 A. Rutka: "Kinderperspektive...," p. 23.

${ }^{27}$ G. Dietz: Hitler Sells...: "Deswegen lehne ich diese Art des persönlich-emotionalen Erzählens ja auch ab. Diesen Generationenroman. Dieses Bedürfnis zu klären, was der Großvater getan hat, um die persönlichen Verstrickungen zu beleuchten. [...] Man hat nur zufällig den gleichen Pass."

${ }^{28}$ Ibidem: "Mir ist durchaus bewusst, dass ich nichts getan habe. Meine Verpflichtung ist als Mensch, nicht als Deutscher."

${ }^{29}$ A. Pyzik: Nowe narracje o Zagładzie, https://www.polityka.pl/tygodnikpolityka/kultura/ ksiazki/233587,1,nowe-narracje-o-zagladzie.read [accessed 13.07.2020]. "Wizja Venemanna więcej ma wspólnego z Singerem niż Kosińskim: nie ma tutaj dosłownego okrucieństwa, jest wizyjny obraz przefiltrowany przez wyobraźnię dziecka, pełną niepokojącego wyczekiwania. Bo wiemy, że zaraz wydarzy się tu tragedia. Póki co jednak słuchamy opowieści zawieszonej w bezczasie, bo dziecko inaczej postrzega upływ czasu."

${ }^{30}$ Ibidem: "z którą pomimo ogólnonarodowej dyskusji nadal sobie nie poradziliśmy." 


\section{"A promising debut!" German Reactions to Close to Jedenew}

The historical facts do not seem to play a role in the German reviews. Helmut Böttiger's review focuses on the literary strategy: The "enigmatic web of sentences, of times, of persons" ${ }^{\text {"31 }}$ serves to avoid unambiguousness in historical terms: "But the message is not clear. It's not made up of slogans. The message is that this is about literature." 32 Instead it makes sense to talk about the "poetic truth,"33 as Georg Diez says in his review:

It is a very musical, almost provocatively melodic piece of literature, which is fed entirely by a feeling of the present and tells of the past in a way as if it were the most natural thing in the world. There is a big amount of naivety in this book, but a kind of broken naivety that differs from guilelessness in the way that it knows exactly what effect it has. It is the book of a generation that no longer asks itself the question of how to deal with German guilt - this story is for them, says Close to Jedenew, above all a story. ${ }^{34}$

The story's naivety appears as a reference to the abstract author, since it mirrors both the narrator's and the author's standpoint. It is noteworthy that no German literary critic refers to the problematic content of stereotypes. Can one explain this by ignorance or by the thematic preoccupation of German reviewers and readers with the Holocaust topic, which narrows their view? Considering Close to Jedenew as a parable on the mechanisms of anti-Semitism, ${ }^{35}$ which shows "the mistrust that is hundreds of years old and only needs an occasion, a suspicion, ${ }^{36}$ most of the German critiques do not refer to Polish history, nor to

${ }^{31}$ H. Böttiger: Zerfallen aller Sicherheiten, https://www.deutschlandfunkkultur.de/zerfallenaller-sicherheiten.950.de.html?dram:article_id=133589 [accessed 13.07.2020]: "ein rätselhaftes Gewebe aus Sätzen, aus Zeiten, aus Personen.”

${ }^{32}$ Ibidem: "Aber die Botschaft ist nicht eindeutig. Sie besteht nicht aus Parolen. Die Botschaft heißt: Hier geht es um Literatur."

${ }^{33}$ G. Kasch: Reiz der Fiktion, https://www.freitag.de/autoren/der-freitag/reiz-der-fiktion [accessed 13.07.2020].

${ }^{34}$ G. Dietz: “Die schönste traurige Geschichte." Die Zeit, 12.01.2006, no. 3, https://www.zeit. de/2006/03/L-Vennemann [accessed 13.07.2020]: "Es ist dabei ein sehr musikalisches, durch sein Thema fast provozierend melodiöses Stück Literatur, das sich ganz aus einem Gefühl von Gegenwart speist und auf eine Art von der Vergangenheit erzählt, als wäre es das Selbstverständlichste auf der Welt. Es steckt ein großes Maß an Naivität in diesem Buch, aber eine Art von gebrochener Naivität, die sich von der Arglosigkeit dadurch unterscheidet, dass sie genau um ihre Wirkung weiß. Es ist das Buch einer Generation, die sich nicht mehr die Frage stellt, wie sie sich zu deutscher Schuld verhalten soll - diese Geschichte ist für sie, das sagt Nahe Jedenew, vor allem eine Geschichte."

${ }^{35}$ K. Frieden: Neuverhandlungen..., p. 86.

${ }^{36}$ G. Dietz: "Die schönste traurige Geschichte...": "Es ist ein Misstrauen, das viele Jahrhunderte alt ist und nur einen Anlass braucht, einen Verdacht." 
Jedwabne. The story is "maybe [set] in Poland" ${ }^{37}$ but no one explores the historical background. But for all of them the German origin of the not clearly identified soldiers is undoubtedly implied. In contrast, Polish readers blame Vennemann for not naming the perpetrators directly - another example of how differently the creation of the abstract reader and the abstract author can look.

\section{Matthias Nawrat: The Numerous Deaths of Grandpa Jurek}

The choice of the second book of this analysis is again motivated by its aspect of transnational narration. This time it is not a German author looking at Eastern Europe but a Polish-born author writing in German about Polish history: Matthias Nawrat, born in Opole in 1979 as Maciej Nawrat. The Numerous Deaths of Grandpa Jurek is his first book to include autobiographic references and is based mainly on the life story of his grandfather Jurek Mrożek. The starting point of the plot is Jurek's funeral in Opole, which leads the grandson's family, now living in Germany, to return to Silesia for a couple of days. The narrator remains anonymous and uses the first-person plural, which makes him part of a not clearly described group of Jurek's descendants. In an interview with Radio Opole, Nawrat said that the impulse to shed light on the family history was the death of his grandparents, which gave him the feeling that "his own life story was dying, too." ${ }^{38}$ Despite the ubiquitous topic of death, the reader gets a humorous depiction not only of Jurek's life but also of Polish history across six decades. Thanks to his cleverness - and to a certain extent audacity - Jurek escapes from the Auschwitz concentration camp. As a food store owner in socialist Poland, he successfully evades the absurd requirements of the planned economy, and in the period of Martial Law, Jurek and his friends oppose the regime with civil disobedience, which results in his undergoing police interrogation.

The book is clearly intended for German recipients, for whom the realia of communism as portrayed in books originally written by authors from post-communist countries may be inexplicable. ${ }^{39}$ Whereas this normally requires fundamental changes in the translation of the original text, Nawrat takes advantage of having grown up and been socialised in Germany for most of his life. He chooses humour to depict Polish history starting from Nazism and continuing through communism, but includes numerous references to earlier times, putting the

${ }^{37}$ A. Neuhaus: "Blick in den Studel." Frankfurter Allgemeine Zeitung, 23.02.2006, no. 46, p. 36: "vielleicht in Polen."

${ }^{38}$ Wszystkie śmierci dziadka Jurka to historia rodzinna opowiedziana na tle historii Polski, http:// radio.opole.pl/365,31,wszystkie-smierci-dziadka-jurka-to-historia-rodz= [accessed 13.07.2020].

${ }_{39}$ A. Hultsch: "Schreiben, um übersetzt zu werden?...," pp. 468-470. 
behaviour of Grandpa Jurek into the Polish tradition of independence fighters. In the course of 400 pages, the novel unfolds a panoramic view of the main cultural and political landscape which appears sometimes quite superficial:

The people in Poland, for example, can look back on many difficult times. But not even the three partitions of Poland in 1772, 1793 and 1795 and its disappearance from the map for more than a hundred years could have hurt them. And he has already told us about the great freedom fighters like Tadeusz Kościuszko and Mr. Wołodyjowski and General Dąbrowski. ${ }^{40}$

In recent decades, a strong presence of writers of Slavic origin writing in German is noticeable. Besides authors of Polish origin, such as Radek Knapp, Dariusz Muszer and Aleksandra Tobor, another productive group of writers is those of Jewish origin who emigrated mainly in the early 1990s from the Soviet Union, including Vladimir Kaminer, Olga Grjasnewa and Lena Gorelik. In recent years, they co-founded the process of post-migration literature production. These authors argue that the label Migrationsliteratur clearly underscores their outsider position, implying at the same time the cultural predominance of the German majority society (whatever this majority may look like) which considers assimilation to be the main goal for every migrant. ${ }^{41}$ Recent texts show that these authors are tired of being constricted to the migration topic, as if to serve as a good example for integration ${ }^{42}$ (see the paradigmatic title of Lena Gorelik's essay, "But you speak German really well!" Why I don't want to be thankful any longer for living here and why tolerance doesn't help ${ }^{43}$ ). So instead of depicting topics like displacement, or the quest for identity, Nawrat chooses to tell the German audience a history lesson about their neighbour country. This can be considered to be an emancipatory step made in order to show the reader the rich history that is intertwined with Germany, instead of confirming and repeating migration literature issues.

${ }^{40}$ M. Nawrat: Die vielen Tode unseres Opas Jurek. Reinbek 2017, p. 353: “Die Menschen in Polen zum Beispiel können auf viele schwere Zeiten zurückschauen. Aber nicht einmal die drei Teilungen Polens in den Jahren 1772, 1793 und 1795 und sein Verschwinden von der Landkarte für mehr als hundert Jahre hätten ihnen etwas anhaben können. Und von den großen Freiheitskämpfern wie Tadeusz Kościuszko oder Herrn Wołodyjowski oder General Dąbrowski habe er uns ja bereits erzählt."

${ }^{41}$ P. Grjasnowa: "Privilegien." In: Eure Heimat ist unser Albtraum. Ed. F. Aydemir, H. Yaghoobifarah. Berlin 2019, p. 130.

${ }^{42}$ The result is highly polemic but pointed essay volumes, such as N. Ljubić (ed.): Schluss mit der Deutschenfeindlichkeit! Geschichten aus der Heimat. Hamburg 2012, and Eure Heimat ist unser Albtraum...

${ }^{43}$ L. Gorelik: „Sie können aber gut Deutsch!“ Warum ich nicht mehr dankbar sein will, dass ich hier leben darf, und Toleranz nicht weiterhilft. München 2012. 


\section{Grandpa Jurek as a Tale about Identity - Polish Opinions}

It is therefore most surprising to find that Polish reviewers constantly refer to the binational background of Matthias Nawrat and thus follow this interpretative pattern even though the author himself states in the foreword to the Polish edition: "Since this publication, I have been hearing the question about who I am, a Pole or a German. [...] But I realise that there is no need any more to ask such a question in Europe." ${ }^{\prime 4}$ The simple fact that Nawrat was born in Poland invites reviewers and literary scholars to explore this topic. And this perfectly well shows the power of text-external knowledge to influence reception. For Małgorzata Zduniak-Wiktorowicz and Brigitta Helbig-Mischewski, the abovementioned recent debate about post-migration writing is considered to be a symptom of a leftwing academic discourse aimed at a levelling of characteristics and categories(!). ${ }^{45}$ Of course, one cannot deny that questions of belonging are crucial for every individual, but their opinion neglects the fact that authors increasingly reject binary thinking and categorization. Agnieszka Palej also interprets the novel as an identity-constructing work process since the narrator gets in touch with another cultural sphere of the "old homeland." ${ }^{36}$ But the grandson's depiction of his relatives in Opole shows no references that would allow us to speak about alienation or a feeling of otherness. The depiction of the grandmother who is always concerned that her relatives in Germany could eventually lack something and therefore stocks plenty of food for their return ${ }^{47}$ shows that this is an iterative act, and thus the Polish and the German sides of the family are always in contact. Additionally, the use of the first person plural makes it hard to speak about an individual identity experience. There are no hints referring to the narrator's perception of his country of origin as the narrator leads his voice to his grandfather: the reader is thus focused on Grandfather's story and perspective.

${ }^{44}$ Cited after: M. Orski: “Jak i gdzie umierał dziadek Jurek.” Odra 2016, no. 10, pp. 115-116, here 115: "Od czasu niniejszej publikacji często słyszę pytanie, kim jestem, Polakiem czy Niemcem. [...] A ja coraz bardziej dochodzę do wniosku, że w Europie nie trzeba już sobie zadawać takiego pytania."

${ }^{45}$ M. Zduniak-Wiktorowicz, B. Helbig-Mischewski: Prosa mit polnischem Hintergrund in Deutschland und Kontexte. In: Migrantenliteratur im Wandel. Junge Prose mit (nicht nur) polnischen Wurzeln in Deutschland und Europa. = Literatura migracyjna $w$ procesie. Młoda proza (nie tylko) polskiego pochodzenia w Niemczech $i$ w Europie. Ed. M. Zduniak-Wiktorowicz, B. Helbig-Mischewski. Leipzig 2016, pp. 11-19, here p. 12.

${ }^{46}$ A. Palej: "W poszukiwaniu korzeni. Współczesna polsko--niemiecka literatura migracyjna i dylematy tożsamości (Sabrina Janesch, Alexandra Tobor, Matthias Nawrat)." Studia Germanica Gedanensia 2019, no. 4, pp. 95-108, here 98: "mamy do czynienia z kształtowaniem się tożsamości postaci literackiej w wieloaspektowej sytuacji migracji i podróży."

${ }^{47}$ M. Nawrat: Die vielen Tode..., p. 350. 
Mieczyslaw Orski explains the Polish focus on identity issues as resulting from the lack of other interesting aspects for the Polish reader. Nawrat's novel is "rather dedicated to the German recipient than to the Polish." ${ }^{48}$ The latter is forced to go again through the whole catalogue of Polish literary and political figures, which surely is exhausting. Orski could have had in mind the frequently recurring educational references, like: "Furthermore, he read Quo Vadis, The Teutonic Knights, With Fire and Sword and The Deluge of Henryk Sienkiewicz, who received the Nobel Prize in 1905 for his books." ${ }^{39}$ Joanna Drynda explicitly supports this educational approach to Polish history: "Nawrat, however, offers a more readable alternative which is more acceptable even to readers who prefer superficial education through entertainment. It is a narrative mode that clearly relies on a situation comedy that is presented in an amiable and sarcastic manner." 50

In comparison to the German audience, a Polish reader finds plenty of connotations when reading the family name of the deceased main character Mrożek. Reading the story with one of the Poland's biggest satiric writers in mind, the stylistic devices of the novel get elevated to a very high level, which Nawrat, according to Orski, cannot satisfy. Despite the very likeable character of Jurek, the tragicomic depiction of the scenes in Auschwitz bother the critic with their naivety (the chapter about Auschwitz is called The so called difficult times of Grandpa Jurek ${ }^{51}$ ) and it is noteworthy that the narrator refers to it only as "Oświęcim, as the world-famous city is called nowadays," ${ }^{2}$ and to Hitler as "the nowadays still globally known politician."53

\section{Grandpa Jurek as a Picaresque Hero - German Opinions}

Tomasz Kurianowicz's enthusiastic review in Die Zeit rates the educational potential of Nawrat's book positively: "Never before has an author succeeded

${ }^{48}$ M. Orski: “Jak i gdzie...," p. 116.

${ }^{49}$ M. Nawrat: Die vielen Tode..., p. 15: "Er las [...] außerdem Quo Vadis, Die Kreuzritter, Mit Feuer und Schwer und Die Sintflut von Henryk Sienkiewicz, der für seine Bücher 1905 den Nobelpreis bekommen hatte."

${ }^{50}$ J. Drynda: "Ein Spiel mit Stereotypen? Zu Matthias Nawrats Roman Die vielen Tode unseres Opas Jurek (2015)." Studia Germanica Posnaniensia 2016, no. 37, pp. 79-89, here 84: "Nawrat aber bietet eine flott lesbare, selbst für den auf oberflächliche Bildung durch Unterhaltung ausgerichteten Leser akzeptablere Alternative. Es ist ein Erzählmodus, der deutlich auf eine liebenswürdig bis sarkastisch dargebotene Situationskomik setzt."

${ }^{51}$ M. Nawrat: Die vielen Tode..., p. 40: "Die sogenannte schwierige Zeit unseres Opas Jurek."

52 Ibidem, p. 40: "Oświęcim wie die weltberühmte Ortschaft heute heißt."

${ }^{53}$ Ibidem, pp. 18-19: "dieser heute noch weltweit bekannte Politiker." 
in condensing Poland's recent history, which is hardly known at all, especially in Germany, so cleverly in a mixture of humour and tragedy." ${ }^{54}$ Kurianowicz considers the humorous depiction, calling it "inverted joke," to be a strategy of coming to terms with fate, a survival strategy. In the tradition of the picaresque novel, the poetic language of the appealing hero Jurek is a conscious attack on the socialist rhetoric. The topos of the picaresque is common to many reviews, like that in Neue Zürcher Zeitung. Additionally, this critic, Rainer Moritz, expresses concern about this humorous narrative since it could be understood as a profanation of the Auschwitz account. But he explains this way of storytelling by reference to Jurek's character, which needs an exit strategy to go on living. ${ }^{55}$ For every reviewer the biographical context of the author is undoubted, but they suggest not to reduce the reception to it. The interplay between autoreferential and fictional devices makes the book interesting and does not reduce the informational content that is crucial for the German reception. A critical perspective is drawn in a review written by Tilman Strasser, for whom Polish history cannot be represented poetically: "And indeed, Nawrat overextends himself. Especially by looking at history through poetically polished glasses. Grandpa Jurek beautifies his own biography and spares the mind of the next generation by playing down the horrors. ${ }^{.56}$ Strasser argues that it is not the humorous point of view itself that makes the narrative problematic, but the fact that both the Auschwitz scenes and the scenes of his work life in socialist Poland are depicted in the same poetic manner. "Then the [novel's - E.-M. H.] characteristic feature appears to be laboured humour, even calculated in the worst case." ${ }^{57}$

\section{Summary}

Despite the discussion about whether Nawrat's book should be read autobiographically or not, the plot clearly refers to issues of German and Polish

${ }^{54}$ T. Kurianowicz: "Kopf eines Königs, Körper eines Hofnarrs." Frankfurter Allgemeine Zeitung, 15.10.2015, no. 239, p. 10: "Denn noch nie ist es einem Autor gelungen, die neuere Geschichte Polens, die insbesondere in Deutschland kaum bekannt ist, derart klug in einer Mischform aus Witz und Tragik erzählerisch zu verdichten."

${ }_{55}^{5}$ R. Moritz: Polnische Delikatessen, https://www.nzz.ch/feuilleton/buecher/matthias-na wrats-neuer-roman-polnische-delikatessen-ld.6056 [accessed 13.07.2020].

${ }^{56}$ T. Strasser: Roman „Die vielen Tode unseres Opa Jurek“. Kabale und Opole, https://www. tagesspiegel.de/kultur/roman-die-vielen-tode-unseres-opa-jurek-kabale-und-opole/12445630. html [accessed 13.07.2020]: "Und tatsächlich verhebt sich Nawrat. Erst recht, indem er die Historie durch eine poetisch geschliffene Brille betrachtet. Opa Jurek schönt die eigene Biografie und schont das Gemüt der Nachfolgegeneration, indem er Gräuel verharmlost."

${ }^{57}$ Ibidem: "Dann wirkt der Duktus angestrengt drollig, schlimmstenfalls kalkuliert." 
relations, especially the chapters about national socialism and Jurek's time in Auschwitz. According to Dirk Uffelmann, there are two narration types dealing with binational topics. The first is the reconciliatory narrative, which intends to overcome disputes and discrepancies in reciprocal perceptions. The second one, by contrast, underscores differences and intentionally plays with stereotypes and old wounds. Indeed, one can consider The Numerous Deaths of Grandpa Jurek to be a reconciliatory narration since it features positive depictions: "the Germans are obviously quite different today than they were then, today they are actually the most peaceful people in all of Europe, ${ }^{58}$ or "and that is why there are probably good people in Germany today, not only in Poland, we should remember that," ${ }^{\prime 59}$ which in general evoke the impression of being calculated to some extent.

In the case of Close to Jedenew, the Jedwabne topic is the crucial point of reference for interpretative differences here. As Marta Tomczok states, "The postJedwabne narratives define rather Polish collective identity than Jewish identity, or recreate both, so they include stories that are fundamentally educational or informative, with a very clear and, to some extent, corrective potential." ${ }^{60}$ Vennemann's prose does not meet any of these Polish expectations; the textual structure, the set of characters and the avoidance of facts forestall an educational approach to history, neutral readers might say. But there is no such thing as a neutral perspective on literature, as the reactions and differing opinions about the text demonstrate. "An author does not see the foreign country; he[/she] recreates it through his[/her] own sensitivity." ${ }^{\prime 1}$ And that is also true for every recipient of fictional literature. Vennemann's figures create an emotional view of Poland during World War II. It remains wishful thinking that the empathy established on the textual level should have been applied also in the author's reflections about the topic in interviews.

Two crucial quotes from the novels sum up their intention better than academic debates could do:

${ }^{58}$ M. Nawrat: Die vielen Tode..., p. 27: "die Deutschen sind heute ja offenbar ganz anders als damals, heute sind sie eigentlich das friedlichste Volk in ganz Europa."

${ }^{59}$ Ibidem, p. 47: "Und deshalb gebe es auch heute in Deutschland mit großer Wahrscheinlichkeit gute Menschen, nicht nur in Polen, das sollten wir uns merken."

${ }^{60}$ M. Tomczok: "Po Jedwabnem. Narodziny popularnej opowieści rozliczeniowej." Poznańskie Studia Polonistyczne. Seria Literacka 2015, no. 25, pp. 257-273, here 267: "narracje pojedwabieńskie określają raczej polską tożsamość zbiorową niż tożsamość żydowską, względnie odtwarzają obie te perspektywy, co powoduje, że dużo częściej trafiają się wśród nich opowieści fundamentalnie edukacyjne czy informacyjne o bardzo jasno zarysowanym i w jakiejś mierze także naprawczym potencjale."

${ }^{61}$ Quoted after: P. Fagot: Mémoires et regards..., p. 342: “Un auteur ne voit pas l'étranger, il le recrée selon sa propre sensibilité." 
[T] he greater the shifts in the geometry of the streets and squares and in the chronological sequence of different events, the more significance do stories gain. ${ }^{62}$

[A]t the age of sixteen, we still braid the hair of our dolls every day, arrange them on the window sills and tell each other fairy tales [...]. We make up stories; everything that happens near Jedenew is a story, and if nothing happens, we make up something. ${ }^{63}$

Hence both books are reminders of history, but they resist being instrumentalised by national narratives. They leave it to the readers to learn their own lessons, maybe inspired by the stories' contents, maybe motivated by the examination of historical facts the books allude to. Applying a close reading perspective, the narrators (not the authors!) present history from a very personal point of view, which of course makes the narrations discussable. But it is only the critics that make the books part of a national emplotment which narrows the perception of the whole text. Due to the significance of the Holocaust and World War II for collective and personal memory, it remains the main task and challenge for fictional literature to provoke controversies but not to bother with an overload of naivety.

\section{Bibliography}

Böttiger H.: Zerfallen aller Sicherheiten, https://www.deutschlandfunkkultur.de/zer fallen-aller-sicherheiten.950.de.html?dram:article_id=133589 [accessed 13.07.2020].

Chimiak K.: Unsere Mütter, unsere Väter - Ein Beispiel für historische Unwissenheit und deutsche Stereotype, https://zeitgeschichte-online.de/themen/unsere-muetterunsere-vaeter-ein-beispiel-fuer-historische-unwissenheit-und-deutsche [accessed 13.07.2020].

Dietz G.: Hitler Sells, https://taz.de/Archiv-Suche/!5186550\&s=georg\%2Bdiez\%2Bvenne mann/ [accessed 11.07.2020].

Dietz G.: "Die schönste traurige Geschichte." Die Zeit, 12.01.2006, no. 3, https://www. zeit.de/2006/03/L-Vennemann [accessed 13.07.2020].

${ }^{62}$ M. Nawrat: Die vielen Tode..., p. 213: “je grösser die Verschiebungen sowohl in der Geometrie der Straßen und Plätze als auch in der zeitlichen Abfolge verschiedener Begebenheiten sind, desto größere Bedeutung [gewinnen] Geschichten."

${ }^{63}$ K. Vennemann: Nahe Jedenew..., p. 65: "wir flechten mit sechzehn Jahren noch immer täglich Zöpfe in die Haare unserer Puppen, die wir auf die Fensterbänke arrangieren, und erzählen uns von Märchen, nichts lieber als das. Wir denken uns Geschichten aus, alles was bei uns nahe Jedenew passiert, ist eine Geschichte, und wenn nichts passiert, denken wir uns etwas aus." 
Drynda J.: "Ein Spiel mit Stereotypen? Zu Matthias Nawrats Roman Die vielen Tode unseres Opas Jurek (2015)." Studia Germanica Posnaniensia 2016, no. 37, pp. 79-89.

Fagot P.: Mémoires et regards. Le thème de la Pologne dans la prose littéraire allemande (1949-1990). Frankfurt 2001.

Frieden K.: Neuverhandlungen des Holocaust: mediale Transformationen des Gedächtnisparadigmas. Bielefeld 2014.

Gorelik L.: „Sie können aber gut Deutsch!“ Warum ich nicht mehr dankbar sein will, dass ich hier leben darf, und Toleranz nicht weiterhilft. München 2012.

Grjasnowa O.: "Privilegien." In: Eure Heimat ist unser Albtraum. Ed. F. Aydemir, H. Yaghoobifarah. Berlin 2019, pp. 130-139.

Hähnel-Mesnard C.: "Die Inszenierung von Zeugenschaft im Roman Nahe Jedenew (2005) von Kevin Vennemann.” In: Der Nationalsozialismus und die Shoah in der deutschsprachigen Gegenwartsliteratur. Ed. T. Fischer, P. Hammermeister, S. Kramer. Amsterdam 2014, pp. 168-186.

Herder J.G.: Ideen zur Philosophie der Geschichte der Menschheit, Band 2. Berlin-Weimar 1996, pp. 279-282.

Hiemer E.-M.: "Der Zweite Weltkrieg im polnischen Kino. Jüngste filmische Annäherungen und deren Rezeption in Polen und Deutschland.” Poznańskie Studia Slawistyczne 2017, no. 12, pp. 123-138.

Hiemer E.-M.: Autobiographisches Schreiben als ästhetisches Problem. Jüdische Vielfalt in der polnischen und deutschen Gegenwartsliteratur. Wiesbaden 2018.

Hultsch A.: "Schreiben, um übersetzt zu werden? Tschechische Literatur zwischen Originalität und ,euroromán.” Zeitschrift für Slawistik 2010, no. 55/4, pp. 464-479.

Kasch G.: Reiz der Fiktion, https://www.freitag.de/autoren/der-freitag/reiz-der-fiktion [accessed 13.07.2020].

Kochanowska-Nieborak A.: Das Polenbild in Meyers Konversationslexika des, langen' 19. Jahrhunderts. Frankfurt 2010.

Kramer S.: "Identifying with the Victims in the Land of the Perpetrators: Iris Hanika's Das Eigentliche and Kevin Vennemann's Nahe Jedenew." In: Persistent Legacy - The Holocaust and German Studies. Ed. E. McGlothlin, J.M. Kapczynski. Rochester, NY, 2016, pp. 159-177.

Kurianowicz T.: “Kopf eines Königs, Körper eines Hofnarrs.” Frankfurter Allgemeine Zeitung, 15.10.2015, no. 239, p. 10.

Ljubić N. (ed.): Schluss mit der Deutschenfeindlichkeit! Geschichten aus der Heimat. Hamburg 2012.

Moritz R.: Polnische Delikatessen, https://www.nzz.ch/feuilleton/buecher/matthiasnawrats-neuer-roman-polnische-delikatessen-ld.6056 [accessed 13.07.2020].

Nawrat M.: Die vielen Tode unseres Opas Jurek. Reinbek 2017.

Neuhaus A.: "Blick in den Studel." Frankfurter Allgemeine Zeitung, 23.02.2006, no. 46, p. 36.

Orski M.: "Jak i gdzie umierał dziadek Jurek.” Odra 2016, no. 10, pp. 115-116.

Palej A.: "W poszukiwaniu korzeni. Współczesna polsko-niemiecka literatura migracyjna i dylematy tożsamości (Sabrina Janesch, Alexandra Tobor, Matthias Nawrat)." Studia Germanica Gedanensia 2019, no. 4, pp. 95-108.

Pyzik A.: Nowe narracje o Zagładzie, https://www.polityka.pl/tygodnikpolityka/kultura/ ksiazki/233587,1,nowe-narracje-o-zagladzie.read [accessed 13.07.2020]. 
Rutka A.: "Kinderperspektive und Märchenform als Modi der erinnerungslosen Auseinandersetzung mit der Shoah in aktuellen Roman der dritten Generation." Roczniki Humanistyczne 2017, no. 5, pp. 93-107.

Schmid W.: Narratology. An Introduction. Berlin 2010.

Smoleński P.: Co wolno młodemu Niemcowi, https://wyborcza.pl/1,75410,4559484.html [accessed 13.07.2020].

Strasser T.: Roman „Die vielen Tode unseres Opa Jurek“. Kabale und Opole, https:// www.tagesspiegel.de/kultur/roman-die-vielen-tode-unseres-opa-jurek-kabale-undopole/12445630.html [accessed 13.07.2020].

Tomczok M.: "Po Jedwabnem. Narodziny popularnej opowieści rozliczeniowej." Poznańskie Studia Polonistyczne. Seria Literacka 2015, no. 25, pp. 257-273.

Uffelmann D.: "Deutscher Kommerz mit polnischer Literatur über jüdische Themen: Maria Nurowska, Andrzej Szczypiorski und Dariusz Muszer.” In: Osteuropäischjüdische Literaturen im 20. und 21. Jahrhundert. Identität und Poetik = Eastern European Jewish Literature of the 20th and 21st Centuries. Ed. K. Smola. München 2013, pp. 298-322.

Vennemann K.: Nahe Jedenew. Frankfurt 2005.

Wszystkie śmierci dziadka Jurka to historia rodzinna opowiedziana na tle historii Polski, http://radio.opole.pl/365,31,wszystkie-smierci-dziadka-jurka-to-historia-rodz= [accessed 13.07.2020].

Zduniak-Wiktorowicz M., Helbig-Mischewski B.: Prosa mit polnischem Hintergrund in Deutschland und Kontexte. In: Migrantenliteratur im Wandel. Junge Prose mit (nicht nur) polnischen Wurzeln in Deutschland und Europa. = Literatura migracyjna $w$ procesie. Młoda proza (nie tylko) polskiego pochodzenia $w$ Niemczech $i$ w Europie. Ed. M. Zduniak-Wiktorowicz, B. Helbig-Mischewski. Leipzig 2016, pp. 11-19.

Elisa-Maria Hiemer

\section{Odrobiona lekcja?}

Obraz Polski podczas drugiej wojny światowej

na przykładzie najnowszej literatury niemieckiej i jej odbioru w dyskursie publicznym

Abstrakt: Autorka artykułu, opierając się na teorii narratologa Wolfa Schmida, pokazuje wpływ elementów tzw. abstrakcyjnego wymiaru na recepcję dzieł Kevina Vennemanna Blisko Jedenew (2005, pol. 2007) i Matthiasa Nawrata Wszystkie śmierci dziadka Jurka (2015, pol. 2016). Ten abstrakcyjny wymiar - będący wytworem osobistych przekonań i indywidualnych „doświadczeń literackich” - pomaga wyjaśnić sprzeczne opinie na temat tego samego dzieła literackiego, zależące często (ale nie wyłącznie) od różnej wiedzy i świadomości historycznej. Odbiór w mediach i w dyskursie naukowym odzwierciedla również schematy i dyskursy, które nie dają się wyjaśnić samym tekstem. Autorka twierdzi, że odbiorca jest pod silnym wpływem osobistej historii autora, mimo że obie książki nie są autobiografiami, co znacznie ogranicza możliwości interpretacji.

SŁOWA KLUCZE: Kevin Vennemann, Matthias Nawrat, procesy odbioru, krytyka literacka, dyskurs medialny i naukowy 
Elisa-Maria Hiemer - dr, badaczka w Instytucie Herdera do Badań Historycznych nad Europą Środkowo-Wschodnią w Marburgu. Autorka dwóch monografii poświęconych polsko-żydowskiej i niemiecko-żydowskiej literaturze: Generationenkonflikt und Gedächtnistradierung. Die Aufarbeitung des Holocaust in der polnischen Erzählprosa des 21. Jahrhunderts (2012) i Autobiographisches Schreiben als ästhetisches Problem. Jüdische Vielfalt in der polnischen und deutschen Gegenwartsliteratur (2018). Razem z trójstronnym zespołem badawczym przygotowuje Handbook of Polish, Czech, and Slovak Holocaust Fiction. Od niedawna zajmuje się kulturoznawczym projektem dotyczącym planowania rodziny w Polsce.

Elisa-Maria Hiemer - dr, postdoc researcher at the Herder-Institute for Historical Research on East Central Europe, Marburg. She is the author of two monographs dealing with Polish-Jewish and German-Jewish literature (Generationenkonflikt und Gedächtnistradierung. Die Aufarbeitung des Holocaust in der polnischen Erzählprosa des 21. Jahrhunderts, 2012, and Autobiographisches Schreiben als ästhetisches Problem. Jüdische Vielfalt in der polnischen und deutschen Gegenwartsliteratur, 2018). Together with a trilateral team of researchers she is currently preparing the Handbook on Polish, Czech, and Slovak Holocaust Fiction. Besides the topic of the Holocaust and Jewish literature, she recently enlarged her research interest with a new project on family planning in Poland. 